\title{
7. 簡便な低高度プラットフォームを用いた文化財調査
}

\author{
内田 恭司*・森 大**
}

\section{1.はじめに}

埋蔵文化財発掘調査においては従来から航空写真測 量技術を利用した調查結果の記録が行われてきた。そ こでは, 図化用カメラで発掘現場の上空からステレオ 写真を撮影し，図化機を用いて等高線図や断面図等の 図面作成が一般的に行われている。これまで，空中写 真の撮影には経済性を考慮してラジコンヘリコプタが 使われることが多かった。しかし，本格的なラジコン ヘリコプタは飛行だけでも高いレベルの専門技術を要 し, さらに写真撮影技術も加えると, 経験を積んだ専 門の操縦士以外には実施が難しく, 発掘調査工程の自 由度を低減させる要因となっていた。

己れに対して, 近年, ホバリングや飛行時の姿勢制 御を機体が自律的に行い，操作が比較的容易な無人飛 行体が利用可能になってきた。そのような新しい撮影 プラットフォームを導入することで，埋蔵文化財の発 掘調査等での空中写真撮影を簡便でより一般的なもの にすることが出来る。

本報では, 埋蔵文化財調査への UAVの利用定着を 前提として，ドイツのマイクロドローンズ社が開発し た小型の無人飛行体システムを紹介し，それを用いて 実施した試験的な埋蔵文化財の調査結果を報告する。

\section{2.マイクロドローンズ UAV システム}

\section{1 機体の概要}

本報告で試験的な埋蔵文化財の空中撮影に使用した UAV はドイツのマイクロドローンズ社製のものであ る。同社の飛行体には, 可載重量約 $200 \mathrm{~g}$ の $\mathrm{md} 4-200$ 型 (図 1 ) と同1.2kgの md4-1000型（図 2 ) がある（2009 年 9 月現在)。

md4-200と1000はともに 4 枚のロータを持つクワッ ドコプタと呼ばれる垂直離着陸機（VTOL）で，垂直 離着陸と任意方向への飛行, 定点でのホバリングと機

* 国際文化財株式会社

**国際航業株式会社

「写真測量とリモートセンシング」VOL. 48, NO. 5, 2009

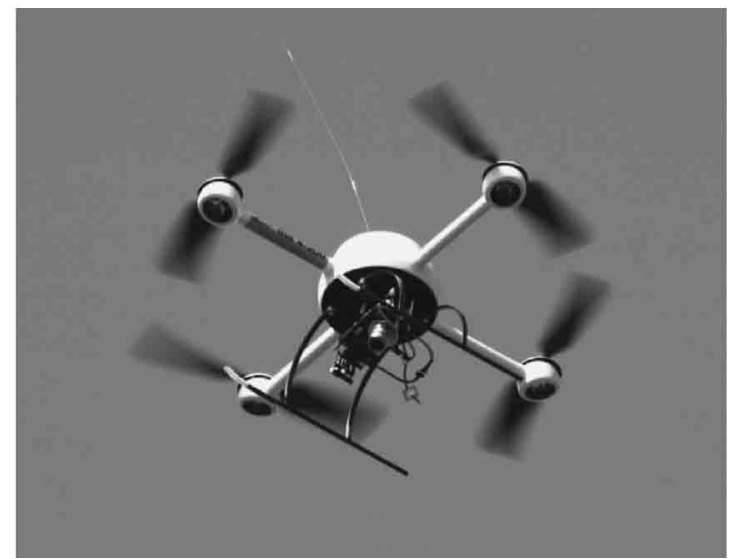

図 1 md4-200

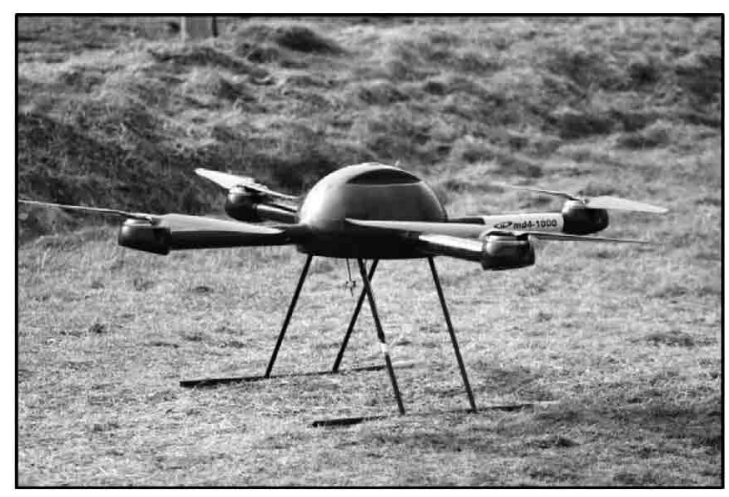

図 $2 \mathrm{md} 4-1000$ のプロトタイプ

体中心を軸とする水平回転ができる。

md4-200は2006年末の 1 号機登場から2008年末まで に欧州を中心に 400 機以上が普及し, 次のような種々の 分野で利用されている。

・消防・救助：災害現場の状況把握

・安全保障：国境監視・パトロール

- 考古学：遺跡調査・計測

・写真撮影・報道：静止画, ビデオ撮影

・環境調査：空中撮影による植生・動物調査

一方, md4-1000は2009年秋にリリース予定である。

表 1 に両機種の主要諸元を示す。 $m d 4-200$ の機体の 大きさは, 前後, 左右のロー夕軸間でそれぞれ $70 \mathrm{~cm}$ 程 
表 $1 \mathrm{md4}-200$ 及び1000型機の諸元

\begin{tabular}{ccc}
\hline & $\mathrm{md} 4-200$ & $\mathrm{md} 4-1000$ \\
\hline 機体重量 $(\mathrm{kg})$ & 0.7 & 3.9 \\
可載重量 $(\mathrm{kg})$ & 0.2 & 1.2 \\
軸間距離 $(\mathrm{cm})$ & 70 & 140 \\
連続飛行時間 $($ 分 $)$ & 20 & 80 \\
$(200 \mathrm{~g}$ 搭載時 $)$ & & \\
\hline
\end{tabular}

度, 高さ約 $20 \mathrm{~cm}$ とコンパクトである。機体はほとんど が炭素繊維素材で構成され, 本体重量が $1 \mathrm{~kg}$ 以下と非 常に軽い。大型の md4-1000でも機体重量 $4 \mathrm{~kg}$ 未満で ある。

各ロータはリチウムポリマー電池を動力源とする独 立した 4 つの電動モータでそれぞれ駆動される。 md4-200と1000の飛行時の騒音はホバリング時に機体 から $3 \mathrm{~m}$ の距離でそれぞれ $63 \mathrm{db}$ と $71 \mathrm{db}$ と比較的静か である。

両機には図 1 で見られるように，機体中央下部にセ ンサ等を搭載することができる。md4-200型機, 1000型 機でそれぞれ約 $0.2 \mathrm{~kg}, 1.2 \mathrm{~kg}$ の搭載が可能である。力 メラやビデオを搭載する場合, 専用のマウントが用意 されており, 地上からの無線制御や自動飛行プログラ ムにより, シャッ夕の制御, 撮影方向, 角度の調整等 が可能となっている。

\section{2 操縦を容易にする機能}

従来, ある程度の高度での無人へリコプ夕操縦は, 機体の姿勢を操縦者が地上から正確に把握することが 難しいため, 高度な操縦技術が必要と言われていた。 md4-200ならびに1000の機体には他の先端的な UAV と同様に GPS や姿勢情報センサ（加速度計，方位計 等）が搭載され，自己位置と姿勢をリアル夕イムに自 動制御をする仕組みとなっており，操縦者の負担を軽 減できる（Meister et al., 2007）。例えば，機体を上 昇させた後に操縦装置の操作を止めれば md4 4 はその 場でホバリングを続ける。そのため, 無線操縦をしな がら写真撮影を行う場合でも, 操縦者が撮影夕スクに より注意を払うことができる。さらには後述のように 事前に飛行ルートを機体に登録することでプログラム 飛行（自動飛行）も可能となっている。

機体重量が数 $\mathrm{kg}$ クラスの小型 UAV は可載重量が 小さいため, 一般的に小型の低精度な姿勢センサしか 搭載できない。md4も同様であるが, 機体に実装したプ ログラムで GPS と姿勢センサのデータからほぼリア
ルタイムに必要なレベルの自己位置と姿勢データを求 め，飛行の自律制御を実現している。

機体姿勢等が自動制御されるため, 基本的な操縦操 作の習得は容易である。マイクロドローンズ社では, 機体の離陸, 垂直上昇と単純な左右旋回, 前後移動な どの基本的飛行操作を半日で無理なく習得させるト レーニングプログラムを策定し，新規ユーザに指導を 行っている。

また，操縦の支援機能に加えて危険回避についても 大型のUAVに見られる機能を備えている。例えば, 電 池の残量が一定值を下回った場合や無線操縦の信号が 機体に届かなくなった場合，地上局に警告を表示する とともに, 自動着陸やあらかじめ設定した危険回避行 動を始めるようにプログラミングされている。

\section{3 ベースステーションとソフトウェア}

$\mathrm{md} 4$ 無人飛行体システムでは機体に加えて, UAV の利用を支援するベースステーションとソフトウェア が用意されている。

ベースステーションは飛行中の機体からの種々の データや映像をダウンリンクするための受信機とアン テナ，及び利用支援ソフトウェアを搭載したパーソナ ルコンピュータ等から構成されている。

利用支援ソフトウェアは観測前後や観測中の様々な 場面で活用ができる複数の機能を一つの統合インター フェースから呼び出せるようになっている。四 3 は飛 行中の支援ソフトウェアの表示例である。ビデオ映像 と機体の位置 - 姿勢, 機器の稼動状況がリアルタイム で地上システムに伝送され，モニ夕画面上で確認する ことができる。

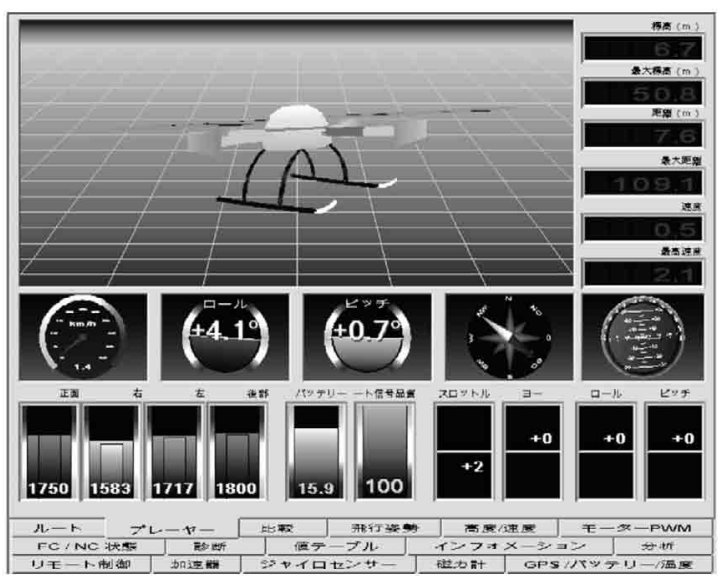

図3飛行状況のデータ表示画面 


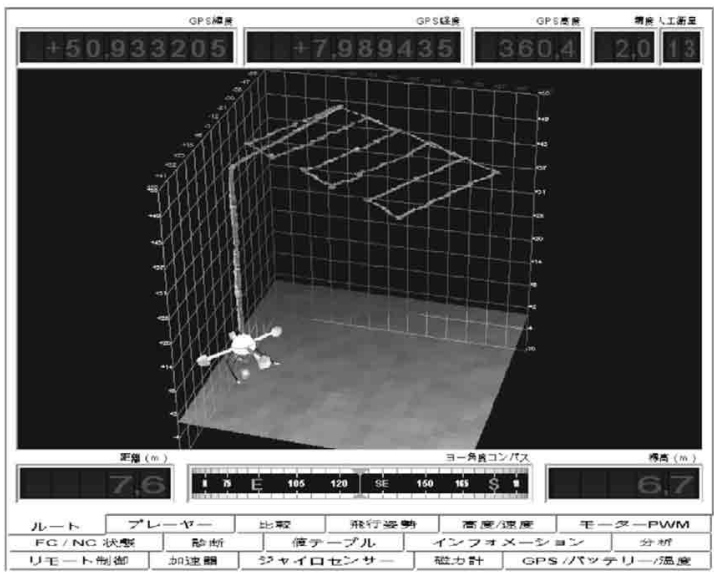

図 4 飛行結果の再現

飛行前後には飛行ルート計画機能でプログラム飛行 計画の策定・登録や飛行状況の再現（図 4 ）が行える。 飛行計画の策定は一般ユーザでも分かりやすいよう に，航空写真等の参照画像を背景に表示しながら，マ ウス操作で飛行ルートを書き込むことが出来る等, 容 易な利用性を目指している。

さらに, 飛行後の保守・点検のために飛行データの 解析機能も付属しており，飛行中に機体のメモリに記 録したモー夕や姿勢制御の動作記録を基に，動作異常 箇所の検出や原因推定, 対応策を示した診断レポート の表示が行われる。

\section{3．埋蔵文化財調査への適用}

\section{1 概 要}

埋蔵文化財調查への md4-200型機の利用性を検討 するために, 実際の発掘現場で試験的に撮影を実施し, 撮影結果から調查図面の作成を試みた。

撮影対象は約 $40 \mathrm{~m} \times 27 \mathrm{~m}$ の広さの, 東海地方のある 低湿地遺跡の発掘現場とした。

撮影時の天候は快晴で最大 $3 \mathrm{~m} / \mathrm{s}$ ほどの風があっ たが，概ね良好な飛行条件であった。

\section{$3.2 \mathrm{md4}-200$ 用いたステレオ画像の撮影}

md4-200の機体下部に, 1,200万画素のコンパクトデ ジタルカメラを装着し，マニュアルモード（シャッタ スピード $=1 / 1000$, 焦点距離 $=\infty)$ に設定して撮影に 臨んだ。

今回の試験では, 対象とした遺構が比較的小規模で 撮影枚数が少ないため, プログラム飛行ではなく, 無 線操縦による飛行と撮影を実施した。UAVの操縦は
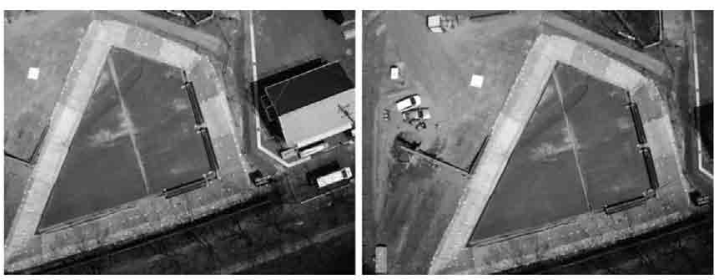

図 5 UAV から撮影したステレオ画像

一般の測量技術者が数時間の訓練の後, 行った。

撮影は発掘現場内から機体を離陸させ，ほぼ垂直に 約 $60 \mathrm{~m}$ 上昇した後，ホバリングをしながら直下にカメ ラを向けて 1 枚目を撮影し, 次いでステレオ撮影のた めに機体を水平方向に約 $18 \mathrm{~m}$ 移動して 2 枚目の撮影 を行った。撮影結果のステレオ画像を図 5 に示す。

撮影時にはリアルタイムに地上に伝送されたカメラ のファインダ映像を補助者が見ながら撮影のタイミン グを操縦士に伝えてシャッ夕を切った。一組のステレ オ画像を撮影するのに, 今回は離陸から着陸までおよ そ5 分であった。

なお，撮影時には写真に映り込むように対空標識を 設置し, トータルステーションでその 3 次元座標を求 めた。

\section{3 写真測量システムによる解析}

取得した画像を, 三次元写真計測・困化システムを 使って計測・困化した。使用したソフトウェアは倉敷 紡績株式会社製 Kuraves $-\mathrm{G}^{2}$ である。計測・困化工程は 通常のラジコンヘリコプタを用いた撮影の場合と同様 に進め, カメラキャリブレーション, 標定, 自動対応 点処理による地表面モデルとオルソ画像の作成, 図化, 等高線図・断面図の作成を試みた（内田ほか，2007）。 図 6 に作成した地表面モデルとオルソ画像を示す。

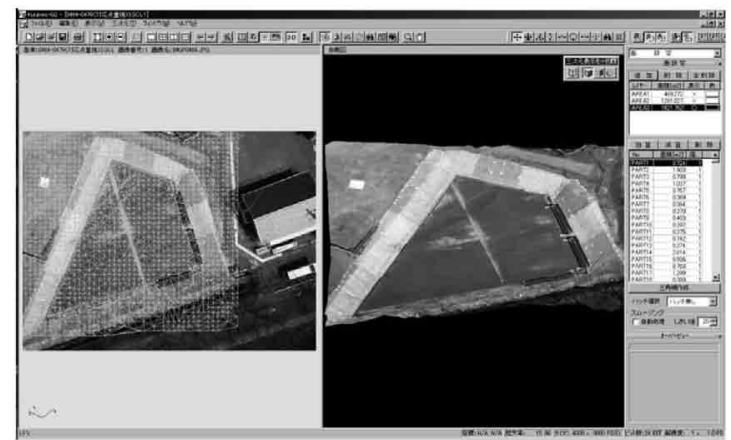

図 6 地表面モデルとオルソ画像の作成 


\section{4 調査結果}

自動対応点探索処理により求めた標高值と困化結果 を重ね合わせた遺跡調査面の等高線困を困 7 に示す。 また，図 7 上に示した断面位置 $\mathrm{A}-\mathrm{A}$ に沿った断面図 を図 8 に示す。それらの図には, 発掘現場の地表面に ある数 $10 \mathrm{~cm}$ 程度の起伏が比較的明瞭に捉えられてい る。

また，現地調査の際にトータルステーションで実測 した 5 力所の参照点の三次元座標と写真計測により求 めた座標值の比較を表 2 に示す。表 2 の計測結果は写 真上で地上測量との対応がやや不明瞭であった点で 5 $\mathrm{cm}$ 程度を示した他は概ね良好な結果であった。

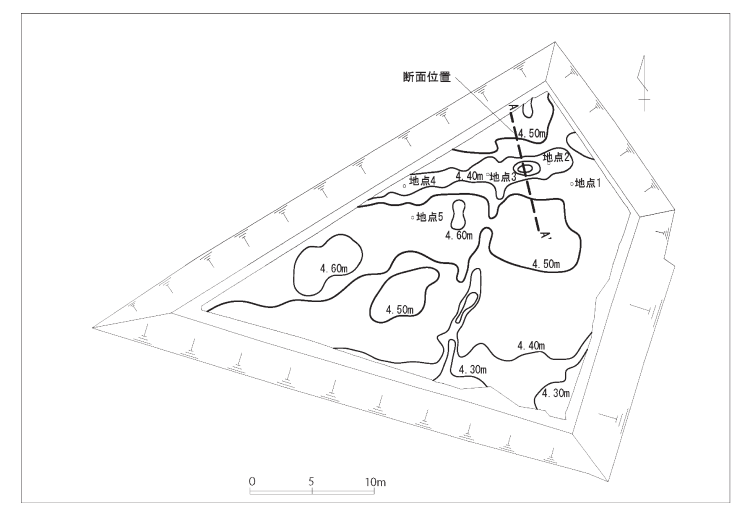

図 7 等高線図

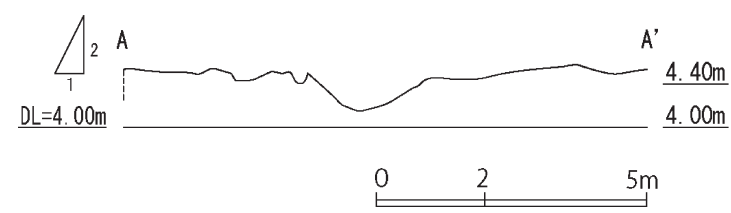

図 8 断面図

表 2 写真測量と地上測量により求めた標高值の比較

\begin{tabular}{|c|c|c|c|}
\hline 地点 & 写真測量 $(\mathrm{m})$ & 地上測量 $(\mathrm{m})$ & $\Delta$ 差異 $(\mathrm{m})$ \\
\hline 1 & 4.484 & 4.472 & 0.012 \\
\hline 2 & 4.361 & 4.361 & 0.000 \\
\hline 3 & 4.330 & 4.302 & 0.028 \\
\hline 4 & 4.383 & 4.333 & 0.050 \\
\hline 5 & 4.543 & 4.530 & 0.013 \\
\hline
\end{tabular}

\section{5 文化財調査への UAV の利用性}

今回の試行では人手によるUAVの操縦で撮影を 行ったが, 専門の操縦士ではない一般の測量技術者が
数時間の訓練の後, 比較的容易に撮影を行うことがで きた。撮影結果を写真計測・困化ソフトウェアを用い て解析処理をした結果, 従来法と遜色の無い等高線困 や断面困等の調査資料を作成することができた。

現状では調査の一般的な仕様の関係でコンパクトデ ジタルカメラを撮影に用いることが難しいが, md4-1000が利用可能になり計測用カメラの搭載が可 能になれば十分に現行撮影法の代替が可能になると考 えられる。

\section{4. おわりに}

本報では応用分野の調查者が比較的容易に取り扱 之, 数 $10 \mathrm{~m}$ 上空からの観測に「簡便な足場」のように 利用できると期待される小型 UAV を紹介し, 埋蔵文 化財の発掘現場における試験撮影の結果を報告した。

埋蔵文化財発掘調査では, 調査の前と調査する面数 に応じて複数回，ラジコンヘリコプタを使用した景観 撮影が行われることが多く, 予め設定した飛行ルート を自動飛行できるUAVを利用すれば毎回同じアング ルの撮影が可能となり作業効率が高まると期待され る。現在, 景観撮影は要求仕様上, 中判力メラの使用 が必要であり, 小型の md4-200では対応が難しい点も あるが, 今後, 搭載重量の大きな md4-1000が利用でき れば十分に実用化が可能と考えられた。

今後, 今回と同様に md4-1000による試験撮影を実 施し, その利用性を検討したい。さらに, 技術的課題 とともに運用上の課題を整理・解決し, 簡便な空中調 査プラットフォームとしての UAVを実務に定着させ ていきたい。

\section{参考文献}

内田恭司, 岡安光彦, 木村淳一, 2007. 石江遺跡群に おけるデジタル写真測量, 日本考古学協会第73回総 会ポスターセッション, pp.164-165.

マイクロドローンズ社：http://www.microdrones. com/ (2009年 9 月 5 日確認).

Meister, O., Mönikes, R., Wendel, J., Frietsh, N., Schlaile, C., and Trommer, G.F. 2007. Development of a GPS/INS/MAG Navigation System and Waypoint Navigator for a VTOL UAV. Unmanned Systems Technology IX, Proc. of SPIE Vol. 6561, 65611D. 